\title{
Strengthening Community Capacity in Detroit to Influence Policy Change for Health Equity
}

\author{
Chris M. Coombe \\ University of Michigan
}

Angela G. Reyes

Detroit Hispanic Development Corporation

Sonya Grant

Southeast Michigan Community Alliance

\author{
Barbara A. Israel \\ University of Michigan \\ Jaye Clement \\ Henry Ford Health System
}

Richard Lichtenstein

University of Michigan

Sherita Smith

Detroit Hispanic Development Corporation

\begin{abstract}
Policy and systems change is essential to attaining public health equity, and involving communities disproportionately experiencing health inequities is critical. Successful policy mobilization requires specific community capacities, many of which exist in marginalized communities but can be strengthened and amplified. Yet attention to strengthening capacity of communities historically excluded from the policy process has been limited. This study applies a community capacity framework to analyze Neighborhoods Working in Partnership (NWP), a multiyear, community-based participatory initiative to strengthen skills and capacity of Detroit residents to equitably engage with diverse partners in all aspects of the policy process. Findings indicate NWP strengthened key dimensions of policy capacity, including skills, participation, leadership, and community power. We discuss strengths and limitations of NWP, and implications for strengthening capacity of disenfranchised communities to engage in local policy action toward the long-term goal of community well-being and equity.
\end{abstract}

\begin{abstract}
"The most important thing about the training is knowing that I have power that will positively impact my neighborhood and that now I know how to use it."

(Workshop participant)
\end{abstract}

\section{Background}

There is considerable evidence that stressors in the social and physical environment and lack of access to resources contribute to poorer health and widening racial/ethnic and economic inequities (Braveman, Cubbin, Egerter, Williams, \& Pamuk, 2010; Israel et al., 2010; Link \& Phelan, 1995; Schulz, Williams, Israel, \& Lempert, 2002). Low-income urban communities and communities of color are disproportionately affected, for example, through exposure to deteriorated housing and neighborhood conditions such as blight and crime, and limited access to jobs and quality services and amenities that can help to protect health (Schulz \& Northridge, 2004; Williams \& Collins, 2001). These structural conditions are influenced by state and national as well as local and organizational policies, and so policy change is an important strategy to have a more sustained impact on community well-being (Phelan, Link, \& Tehranifar, 2010; Williams \& Jackson, 2005). Thus, addressing the underlying social determinants of health equity requires the capacity to work effectively with policy and decision makers to address factors such as housing, neighborhood conditions, education, and employment opportunities foundational to the attainment of public health.

A successful policy advocacy campaign requires an essential set of skills or capacities (Freudenberg, Rogers, Ritas, \& Nerney, 2005; Minkler, Vasquez, Tajik, \& Petersen, 2008; Ritas, 2003). Successful models for influencing policy emphasize the need to engage communities that have historically been marginalized or excluded from this process (e.g., low-income communities, communities of color) in policy campaigns (Freudenberg \& Tsui, 2014; Themba-Nixon, Minkler, \& Freudenberg, 2008). Engagement of community members in policy change efforts can lead to increases in power 
through translation of concerns into concrete action and identification of policy solutions to issues inadequately addressed by current policy (Cheezum et al., 2013; Ritas, 2003; Roe, Minkler, \& Saunders, 1995; Themba-Nixon et al., 2008; Themba, 1999). Many communities regularly engage in policy advocacy efforts, often with a great deal of skill and success. However, relatively few examples exist of initiatives designed to both build on and strengthen dimensions of community capacity, with particular attention to policy advocacy to address determinants of public health and equity (for exceptions, see Minkler, Vásquez, Chang, \& Miller, 2009; Sharpe et al., 2015). The recognition that many of these capacities already exist within marginalized communities, and that they can be strengthened and amplified, is central to community-based participatory approaches to research and action, and underlies the efforts described here. In this article, we use a community capacity framework to analyze Neighborhoods Working in Partnership (NWP), a program to build skills and capacity of residents to engage in the policy change arena, and its implementation in several communities historically excluded from the policy change process and disproportionately experiencing health inequities. The NWP program and evaluation results are reported in detail elsewhere (Cheezum et al., 2013; Israel et al., 2010). In this study we examine capacities that were strengthened through NWP, and implications for community mobilization to change policies that impact neighborhoods and schools, and ultimately community well-being and equity.

\section{Detroit Context}

In recent years, there has been increased national attention to addressing the challenges facing Detroit, including the loss of jobs and population, systematic disinvestment in services and neighborhoods (Detroit Works Project, 2012; Dewar \& Thomas, 2013; Farley, Danziger, \& Holzer, 2000; Kinney, 2016; Sugrue, 1996), and disenfranchisement from political decision-making at city, regional, and state levels (Smith \& Kirkpatrick, 2015). Most notably, city residents were stripped of political representation and civil authority over city government and schools through Public Act 4 imposed by the Michigan legislature in 2011 that allowed the governor to replace democratically-elected public officials with an appointed emergency manager for both local governments and school districts (Legislature, 2011). Although Michigan citizens voted to repeal the law in 2012, the legislature reinstated it a month later by passing Public Act 436 (Legislature, 2012).

Simultaneously, and often overlooked in discus- sions of Detroit, are the considerable resources, ecological assets (Thomas \& Bekkering, 2015), capacities, and strengths that exist within Detroit's neighborhoods and residents. A long history of activism undergirds contemporary Detroit, including involvement in and influence over the Labor and Civil Rights Movements (Farley et al., 2000; Sugrue, 1996; Thompson, 2001), and strong traditions of advocacy, social justice, and critical analyses (Boggs \& Kurashige, 2012; Ward, 2016). The magnitude and nature of Detroit's current challenges, and the need for substantive policy change, requires the engagement of on-the-ground knowledge and expertise of Detroit community residents, and the amplification or extension of those with the skills and capacities to engage in advocacy for policy change toward greater equity.

\section{The Detroit URC: Building Capacity for Policy Change}

Building on this history of activism, Neighborhoods Working in Partnership: Building Capacity for Policy Change, was established in 2007 by the Detroit Community-Academic Urban Research Center (Detroit URC; detroiturc.org), a communitybased participatory research (CBPR) partnership working for over 20 years to improve the health and well-being of Detroit residents (Israel et al., 2001). The Detroit URC aims to promote equitable community-academic partnerships to enhance understanding of how social and physical environments affect health, and to translate that knowledge into interventions, programs, and policies that build upon community resources and strengths to promote health equity.

A major goal of the Detroit URC is to increase capacity of academic, community, and health practice entities to engage in policy advocacy processes, including translation of research findings into policies, dissemination of those policies, and educating decision makers at organizational, local, state, and federal levels regarding opportunities to promote more equitable public policies and ultimately health. To this end, in 2007, with funding from The Skillman Foundation and guidance from PolicyLink, a national research and action institute to advance equity (policylink.org), the Detroit URC developed and implemented Neighborhoods Working in Partnership (NWP), a six-year initiative to build capacity of communities to influence policy and systems change in Detroit (Israel et al., 2010). The overall aims were to strengthen policy advocacy skills within and across Detroit neighborhoods; extend community voices in policy making; and impact policies toward creating healthy neighborhoods. 
NWP was developed within the context of a broader 10-year Good Neighborhoods Initiative (GNI), funded by The Skillman Foundation, to transform six Detroit neighborhoods into supportive environments for children (Colombo, 2016). The GNI aimed to establish local governance groups within each neighborhood, which would develop overall action plans facilitated by neighborhood liaisons. Thus, NWP was intended to enhance the advocacy skills and community capacity needed to effectively impact policy change identified and initiated by neighborhood leaders within the context of the GNI. While NWP did not organize policy campaigns per se, it supported local efforts to address social determinants of health through policy change.

\section{Conceptual Framework and Approach}

In this paper, we apply the concept of community capacity (Goodman et al., 1998) as an overarching framework to analyze the NWP initiative. Goodman and colleagues (1998) defined community capacity as both "the characteristics of communities that affect their ability to identify, mobilize and address social and public health problems," and as "the cultivation and use of transferable knowledge, skills, systems and resources that affect community- and individual-level changes consistent with public health-related goals and objectives" (p. 259). Community engagement in policy change both requires and builds community capacity along a number of dimensions. The 10 dimensions of community capacity initially identified by Goodman and colleagues (1998) include leadership, participation, skills, resources, social and organizational networks, sense of community, understanding of community history, community power, community values, and critical reflection (Goodman et al.). Goodman and colleagues also specify that community capacity may be conceptualized as both a process and outcome by which capacity is created. This framework has previously been adapted to consider community capacity to address environmental health threats (Freudenberg, 2004) and to incorporate CBPR characteristics (Minkler, Vasquez, Tajik \& Peterson, 2008), conceptualizing dimensions of community capacity as factors that contribute to improving the environment and successful collaboration. We build on and extend this work by examining how a community-based participatory process to build policy capacity at the local level and engage residents in advocacy processes also enhances community capacity more broadly.
Neighborhoods Working in Partnership: Strategy and Approach

NWP was collaboratively designed, implemented, and evaluated from 2007-2013 by a team of 15 community and academic partners selected by the Detroit URC, all of whom had extensive experience as effective facilitators and trainers and a wide range of policy advocacy experience. The nine Detroit-based community trainers represented diverse fields (e.g., health policy analyst, librarian, labor organizer, educator, youth advocate, health educator) and the six academic trainers were University of Michigan faculty from the Schools of Public Health and Social Work who were also Detroit URC Board Members. This team used a community-based participatory approach that emphasized equitable collaboration and integrated the extensive skills, experience, and knowledge of community and academic partners (Israel, Schulz, Parker, \& Becker, 2001). The program was designed for community residents in Detroit, and thus integrated deep knowledge of Detroit history and context, both citywide and by specific neighborhoods and populations.

The overall NWP policy capacity building approach combined interactive training, hands-on tools and resources, and ongoing strategic support for groups of both adults and youth mobilizing for policy change (Israel et al., 2010). The curriculum and pedagogy incorporated experiential modes of learning and doing to analyze locally prioritized policy issues. The training used an experiential action learning model (Kolb, 1984), and included a combination of interactive presentations, small group skill-building activities applied to real-life community concerns, reflection, and integration into the ongoing work of the neighborhoods (Browner \& Preziosi, 1995; Johnson \& Johnson, 2017). The program acknowledged and built upon the existing skills, experiences, and knowledge of participants. Further, the content and process of the policy trainings were designed to share and enhance existing participant capacities, as well as build new policy-specific skills, knowledge, and relationships that could be transferred to multiple issues. Because of the existence of unelected governance structures in Detroit and historical circumstances that disenfranchise residents, NWP focused primarily on knowledge and skills needed to impact "little p" policies that local residents may be more likely to influence (e.g., administrative rules, enforcement, organizational policies) rather than "big P" policies (e.g., state and federal legislation). NWP methods, pedagogy, and evaluation results are described in more detail elsewhere (Cheezum et al., 2013; Clynes, 2013; Israel et al., 2010). 
NWP was first implemented as a 4-part series in 7 neighborhoods (2007-2008). Subsequently, the training was carried out in multiple formats ("oneoffs," day-long trainings, workshop series over weeks or months) and for widely different groups (e.g., a high school honors class, nonprofit organization directors, workforce trainees, communitydriven planning participants). The program was funded one year at a time, thus the evaluation design did not allow for multiple year follow up.

\section{NWP Training Curriculum and Relevant Dimensions of Community Capacity}

The NWP training curriculum included separate modules, each of which fosters key competencies (i.e., skill, knowledge, ability) needed for policy advocacy. The modules can be combined into one or more training sessions, or used as stand-alone tools to assist an organization with a specific stage of a policy campaign in which they are engaged. Both the content and the process of the modules are designed to build multiple dimensions of community capacity.

Curriculum content and methods include: understanding what policy is and how it differs from programs; conducting a power assessment; selecting effective policy change strategies; designing a policy advocacy campaign and building coalitions; communicating the policy message; preparing to talk to policy makers; and selecting policy goals based on community-identified criteria. The content and competencies that participants are intended to gain from each module are as follows:

1. What is Policy? Programs vs Policies: Understand the difference between programs and policies; identify program and policy solutions to address specific issues the community has prioritized; know the advantages of a policy approach to change.

2. Using Our Power: Power Mapping: Understand the types and role of power; identify key players, including the decision-maker, supporters, and opponents; map out level and amount of power and relationships to guide policy advocacy strategy.

3. Choosing Strategies for Winning Policy Change: Identify possible policy advocacy strategies and tactics; analyze when to use different strategies based on campaign goals and resources.

4. Designing a Policy Advocacy Campaign: Frame the policy issue; build a coalition; gather information; develop the strategy; engage the public and policymakers; critically reflect on and analyze successes and failures; plan next steps.

5. Using Our Voices: Preparing to Talk with Policymakers: Identify audiences; frame the message for different constituents; create effective talking points; act in coalition to show power; build leadership.

6. Using Communications for Policy Change: Gather information on communications methods; build skills; develop relationships to enhance community voice; plan actions.

7. Choosing the Right Policy Goals: Gather information on community history; develop selection criteria based on community values and history, resources, skills; select short and long term goals that enhance community power.

Each module addressed one or more dimensions of capacity, both as a process and outcome. For example, while the content outcome may be increased knowledge (What is policy?), the activity to gain that knowledge involved a group process in which participants both share information and work together to solve a problem. Table 1 presents the training modules, the dimensions of community capacity particularly highlighted in that module, and how the training activities incorporated and applied those dimensions for policy change, i.e., the particular skills and knowledge gained in the module. As the dimensions are interrelated and may overlap, the table only highlights key capacities developed in each module, and presents skills, knowledge, and abilities together.

For example, as shown in Table 1, Module 2-Powermapping highlights three dimensions of community capacity listed in column 2 - participation, social and organizational networks, and community power. These are defined in column 3 . Specific policy-related skills, knowledge, and capabilities conveyed by this module are listed in the final column.

\section{Methods}

We use a case study approach to describe and analyze the Detroit URC's policy capacity building efforts from 2007 to 2015 . This study draws upon published evaluation findings from the initial NWP series program, as well as evaluation results from carrying out the program in multiple formats for varied audiences from 2007-2013 in conjunction with the GNI and other venues from 2013-2015 within Detroit but not funded by the GNI. We used a participatory and formative evaluation approach that engaged community and academic policy 
Table 1

Training Modules of Building Capacity for Policy Change and Relevant Dimensions of

Community Capacity

\begin{tabular}{|c|c|c|c|}
\hline Training Module & $\begin{array}{l}\text { Relevant Dimensions of } \\
\text { Community Capacity* }\end{array}$ & $\begin{array}{c}\text { Definitions of Each } \\
\text { Dimension Relevant to } \\
\text { Policy Advocacy* }\end{array}$ & $\begin{array}{l}\text { Policy Advocacy Skills, } \\
\text { Knowledge, and Abilities }\end{array}$ \\
\hline $\begin{array}{l}\text { 1-What is Policy? } \\
\text { Programs vs Policies }\end{array}$ & $\begin{array}{l}\text { Leadership } \\
\text { Skills }\end{array}$ & $\begin{array}{l}\text { - Experienced, skilled } \\
\text { leaders willing to address } \\
\text { issues } \\
\text { - Relevant organizational, } \\
\text { scientific, political, and } \\
\text { information-seeking skills }\end{array}$ & $\begin{array}{l}\text { Understand the difference } \\
\text { between programs and } \\
\text { policies; know program } \\
\text { and policy solutions to } \\
\text { address specific issues the } \\
\text { community has prioritized; } \\
\text { understand advantages of a } \\
\text { policy approach to change. }\end{array}$ \\
\hline 2-Powermapping & $\begin{array}{l}\text { Participation } \\
\text { Social/organizational net- } \\
\text { works } \\
\text { Community power }\end{array}$ & $\begin{array}{l}\text { - Broad, active resident } \\
\text { participation to address } \\
\text { issues } \\
\text { - Horizontal and vertical } \\
\text { linkages among partici- } \\
\text { pants, their organizations, } \\
\text { and other groups } \\
\text { - Ability to act to make or }\end{array}$ & $\begin{array}{l}\text { Understand the role of types } \\
\text { of power; identify key } \\
\text { players, including the de- } \\
\text { cision-maker, supporters, } \\
\text { and opponents; map out } \\
\text { level and amount of power } \\
\text { and relationships to guide } \\
\text { policy advocacy strategy. }\end{array}$ \\
\hline
\end{tabular}

3-Choosing Strategies for Policy Advocacy

4-Designing a Policy Advocacy Campaign

5-Using Our Voices -

Talking with Policymakers

6-Communications Plan for Policy Change

7-Choosing the Right Policy Goal
Skills

Understanding of community history

Resources

Social and organizational networks

Sense of community

Skills

Understanding of community history

Skills and Resources Participation

resist change that affects the community's environment

- Relevant organizational, scientific, political, and information seeking skills

- Awareness of previous efforts to address related problems, and understanding of how the community fares relative to others

- Financial, human, and social resources available

- Horizontal and vertical linkages among participants, their organizations and other groups

- Shared identity and a willingness to take action

- Relevant organizational, scientific, political, and information seeking skills

- Awareness of previous efforts to address related problems, and understanding of how the community fares relative to others

- Relevant skills and resources

- Broad cross-section willing to address issues

Leadership

Participation

Community values
- Experienced, skilled leaders

- Broad, active resident participation to address issues

- Shared norms and standards
Frame the issue; build a coalition; gather information; develop the strategy; engage the public and policymakers; critically reflect on and analyze successes and failures; plan next steps.

Identify audiences; frame the message for different constituents; create talking points; act in coalition to show power; build leadership.

Gather information on communications methods; build skills; develop relationships to enhance community voice; plan actions.

Gather information on community history; develop selection criteria based on community values and history, resources, skills; select short long term goals that enhance community power 
Coombe, Israel, Reyes, Clement, Grant, Lichtenstein, Schulz, and Smith

\begin{tabular}{|c|c|c|c|}
\hline Overall training & $\begin{array}{l}\text { Leadership } \\
\text { Participation } \\
\text { Community power } \\
\text { Critical reflection }\end{array}$ & $\begin{array}{l}\text { - Leaders experienced, } \\
\text { skilled, willing to act } \\
\text { - Broad, active resident } \\
\text { participation to address } \\
\text { issues } \\
\text { - Ability to act to make or } \\
\text { resist change that affects } \\
\text { the community } \\
\text { - Ability to analyze success- } \\
\text { es and failures, reflect on } \\
\text { experience, and assess } \\
\text { arguments of others }\end{array}$ & $\begin{array}{l}\text { Training process and content } \\
\text { includes individual, small } \\
\text { group, and collective activ- } \\
\text { ities to share knowledge, } \\
\text { work collaboratively to } \\
\text { combine resources, make } \\
\text { decisions, and reflect on } \\
\text { history and progress. }\end{array}$ \\
\hline
\end{tabular}

Note. Adapted from Goodman et al. (1998), Freudenberg (2004), and Minkler et al. (2008)

trainers, staff, and Detroit URC Board members in all aspects of the evaluation (Coombe, 2012; Patton, 2002). The mixed methods evaluation included closed-ended participant questionnaires administered at each training to evaluate process and outcomes, and in-depth focus groups to assess impact (Cheezum et al., 2013; Israel et al., 2010). In addition, this study draws on findings from analysis and application of formative evaluation results by the policy trainers after each training, periodic assessment of the policy advocacy approach by the entire community-academic trainer team, strategic planning to apply evaluation findings to future programming, and documentation from policy training activities carried out between 2013-2015.

\section{Participants and Program Reach}

During the NWP program from 2007-2013, 778 individuals from seven focus areas of Detroit and citywide participated in at least one policy advocacy workshop. A third (260) participated in more than one training series. Two-thirds of participants were adults, and one-third were youth between the ages of 14-21. Numerous organizations were represented, and one workshop series was conducted for three cohorts of a year-long, organizational development program for nonprofit leaders across the city. In addition, NWP supported three specific Detroit communities over several years in ongoing mobilization efforts, and continued to work with them on issues including: blight and demolition; gun violence and schools; and environmental justice, education, and immigrant rights. Further, a two-year companion project supported by the Robert Wood Johnson Foundation focused on building policy advocacy skills among parents and students to increase their voices to inform policy and systems change of selected schools controlled by the state Education Achievement Authority (detroiturc. org/affiliated-partners/past-projects/84-nta-part nership.html). Capacity building included develop- ing and disseminating a review of evidence-based policies and practices for parent and student engagement, conducting ongoing workshops in high school classes, building networks and leadership, and providing strategic support for specific advocacy actions.

\section{Analyses}

The analysis presented here focuses on assessing the impact of the NWP approach, using the lens of the community capacity framework described above, to identify and analyze ways in which program activities contributed to key short-term outcomes and longer-term impacts. Due to lack of standardization between trainings and limited comparability among types of participants, we did not aggregate evaluation survey results across all trainings. First, we present data indicating the reach of the program in the community. Second, we examine quantitative and qualitative evaluation data from training participants to assess key dimensions of community capacity developed through the training modules. Next, we examine examples of organizations that have applied NWP skills and knowledge to bring about change in their communities, while building sustainable community capacity in the dimensions described above. Finally, we present a more in-depth case example to illustrate how one organization has applied NWP skills and knowledge to address challenges identified in their community.

\section{Results}

\section{Key Dimensions of Community Capacity: Evaluation Results from Training Participants}

Findings from evaluation of the initial training workshops indicated increased community capacity in multiple dimensions (Cheezum et al., 2013; Israel et al., 2010). Below we present findings by several specific dimensions of community capacity 
relevant to policy change, followed by integration of multiple dimensions.

Skills, knowledge, and resources. Across all trainings, between $80-100 \%$ of participants agreed or strongly agreed that they learned new skills, found the training useful, and were satisfied with both the content and process of the training. In response to evaluation items asking participants' assessment of the most important training components, participants indicated learning about the advocacy process, skills, and tools (e.g., powermapping, communicating with policymakers), and group processes that brought people together to learn how to make things happen jointly, network, communicate well with each other, speak out, and be heard. Asked to describe in what ways the training made a difference in their involvement in the community, participants most commonly described learning that they have power and the information, tools, and skills needed to organize and bring about change in their community.

Participation. Active participation to address community concerns is a key dimension of community capacity (Freudenberg et al., 2011). At the end of the initial training series, $88 \%$ of participants expressed that they intended to apply the training to work towards policy change. Results were similar for subsequent workshops, with a range of 70$100 \%$ of participants reporting that they intended to work with others for policy change in the future. In follow-up focus groups, participants described subsequent engagement in a variety of activities to change policies to address neighborhood concerns, including abandoned houses, school safety, immigration reform, unemployment, housing foreclosures, and lack of affordable housing.

Community power. In the initial series, from pre to post program, participants reported a statistically significant increase (mean 3.95 to 4.23 on a scale of $5, p=0.01$ ) in self-efficacy, expressed as having the ability to work for policy change. Participants reported high levels of collective efficacy at both pre and post (4.37 and 4.48 on a scale of $5, p=0.20$ ), measured as the belief that by working together they could change policies affecting their own neighborhood. In focus groups and open-ended comments, participants indicated that the trainings had enhanced their sense of individual and group power and efficacy (Cheezum et al., 2013; Israel et al., 2010). For example, in one training workshop youth role-played a meeting with a policymaker in front of the entire group. During the debriefing session in which she was asked, "How did it feel to talk in front of all those people?" a 16 year-old girl replied, "Like I had a voice!"

A common theme among participants was that they felt empowered to impact change in their community following the trainings. Focus group participants indicated that the NWP training had two important impacts on Detroit residents: the opportunity to work together cohesively on mutually identified problems, and increased empowerment in terms of skills and the belief in their collective ability to effect change. In the words of two NWP training participants:

\begin{abstract}
"The most valuable information that I received from the training is that I can make a change. And now with all of these new resources I now have a clear understanding on getting "the ball rolling" when dealing with change in my community."
\end{abstract}

"Working together - both young and old - our voices will be heard."

Integration of multiple dimensions. The last column of Table 1 presents results along multiple dimensions achieved simultaneously from participation in the training. For example, in the powermapping activity, participants drew upon existing resources within the group, while developing a skill using a new resource that enabled them to act on a pressing community problem that they had prioritized (e.g., enforce anti-dumping laws). In small groups, they analyzed the specific policy issue and identified the decision maker with power to address the issue. They then identified organizations and individuals who were supportive of the policy and could be mobilized for action, and those who would oppose the policy and needed to be countered or resisted. Thus, by engaging in the training activities, residents participated together, identified existing networks and resources that can be activated, and combined knowledge to critically analyze how to build on community strengths to enhance community power and plan effective advocacy strategies to influence the policymaker and resist opponents. Through this process, participants shared community history and values, exhibited leadership, and came away with a stronger sense of community and efficacy. All of these are aspects of community capacity essential for effective policy advocacy.

\section{Application of NWP Approach to Policy Change and Community Capacity}

Table 2 presents selected examples of organizations successfully applying NWP skills and knowledge to bring about change in their neighborhoods, while building sustainable community capacity in key dimensions.

'The first two columns identify the specific 
Coombe, Israel, Reyes, Clement, Grant, Lichtenstein, Schulz, and Smith

Table 2

Selected Accomplishments and Impacts of Neighborhoods Working in Partnership: Building Capacity for Policy Change

\begin{tabular}{|c|c|c|c|c|c|}
\hline & $\begin{array}{l}\text { Learning } \\
\text { about Policy } \\
\text { Advocacy }\end{array}$ & $\begin{array}{l}\text { Skills Used } \\
\text { for } \\
\text { Advocacy }\end{array}$ & $\begin{array}{l}\text { Communica- } \\
\text { tions } \\
\text { with Decision- } \\
\text { makers }\end{array}$ & $\begin{array}{l}\text { Short-term/ } \\
\text { Intermediate } \\
\text { Outcomes }\end{array}$ & $\begin{array}{l}\text { Long-term } \\
\text { Community } \\
\text { Capacity } \\
\text { Impacts }\end{array}$ \\
\hline \multicolumn{6}{|l|}{ Neighborhoods } \\
\hline $\begin{array}{l}\text { Cody Rouge Com- } \\
\text { munity } \\
\text { Action Alliance } \\
\text { (CRCAA) } \\
\text { 2007-2008, } \\
\text { 2012-ongoing }\end{array}$ & $\begin{array}{l}\text { Adults and youth } \\
\text { participated in a } \\
\text { training series, } \\
\text { ongoing support, } \\
\text { and mobilization to } \\
\text { identify and devel- } \\
\text { op policy to reduce } \\
\text { blight. }\end{array}$ & $\begin{array}{l}\text { Framed message, } \\
\text { developed talking } \\
\text { points, identified } \\
\text { location/owners of } \\
\text { blighted properties } \\
\text { in neighborhood, } \\
\text { held media cam- } \\
\text { paign, met with } \\
\text { decision-makers }\end{array}$ & $\begin{array}{l}\text { The campaign } \\
\text { garnered extensive } \\
\text { in-depth media } \\
\text { coverage. CRCAA } \\
\text { met with key pub- } \\
\text { lic official to make } \\
\text { a case for demoli- } \\
\text { tions near schools. }\end{array}$ & $\begin{array}{l}\text { Cody Rouge was } \\
\text { selected to receive } \\
\text { state-funded } \\
\text { demolitions near } \\
\text { schools. }\end{array}$ & $\begin{array}{l}\text { Increased leader- } \\
\text { ship, participation, } \\
\text { skills, ability to } \\
\text { attract resources, } \\
\text { sense of commu- } \\
\text { nity, and power to } \\
\text { influence decisions } \\
\text { affecting their } \\
\text { community }\end{array}$ \\
\hline
\end{tabular}

Youth Development

\begin{tabular}{|c|c|}
\hline $\begin{array}{l}\text { Detroit Hispanic } \\
\text { Development Cor- } \\
\text { poration (DHDC) } \\
\text { 2010-2011- on- } \\
\text { going }\end{array}$ & $\begin{array}{l}\text { Youth participated } \\
\text { in policy advocacy } \\
\text { workshop series } \\
\text { with ongoing sup- } \\
\text { port from policy } \\
\text { trainer and a youth } \\
\text { program staff, who } \\
\text { was trained by } \\
\text { NWP. }\end{array}$ \\
\hline
\end{tabular}

DHDC Youth

Leadership

Council

2009-2010

\author{
Youth Council \\ participated in \\ policy advocacy \\ workshop series \\ with subsequent \\ support from NWP \\ policy trainer and \\ NWP-trained youth \\ program staff.
}

\section{Organized cam- paign to stop layoff of their high school principal, including powermapped to identify influence and supporters, \\ Youth held press conference and demonstration that resulted in a meeting with DPS Emergency Finan- cial Manager.} framed message, used multiple media to communicate

Targeted policy Youth planned and solutions, identified conducted a panel key policy makers, developed communication plan, framed their messages, developed talking points discussion with local and state policy makers to advocate for improvements in schools to reduce drop-out, enhance safety and youth engagement.
The principal, an effective and respected school leader, was reinstated to a district-wide position.

Youth continued to engage with policy makers, local foundations, and community organizations to advocate for improved school environments.
Increased leadership, participation, skills, sense of community, and power of youth to resist negative decisions and make positive change

Increased participation, skills, leadership, social and organizational networks. Increased power and engagement of youth in policy change.

\section{Safety}

\begin{tabular}{ll}
\hline Neighborhood & Youth in ongoing \\
Service Organiza- & youth development \\
tion Youth Initia- & program partic- \\
tives Project & ipated in policy \\
2013-ongoing & advocacy work- \\
& shop series that \\
& focused on policies \\
& to keep guns out of \\
& schools.
\end{tabular}
Framed messag-
es, developed talking points, and practiced meeting with different decision-maker audiences
High school students spoke at community forum and held press conference about the impact of gun violence on their community.

\section{Youth are knowl- edgeable and pre- pared to meet with the governor's aide. Governor vetoed bill that allowed guns in schools.
Increased skills, leadership, civic engagement, and power of youth; applied commu- nity values and understanding of community history to resist policy that would harm the community


Stop the School to Adult community Prison Pipeline 2010 in trainings and leaders participated received ongoing support and technical assistance to address the schoolto-prison pipeline.
Researched policies, linked to other school-to-prison pipeline efforts, developed communications, organized citywide forum
Held Community

Forum attended by Congressman John Conyers.
Congressman

Conyers invited the group to be part of a national coalition being formed to sponsor federal legislation.
Increased leadership, skills and knowledge, and critical reflection to analyze problems and identify solutions; utilized and extended social and organizational networks from local to national level

\section{Education}

\begin{tabular}{|c|c|c|c|c|c|}
\hline $\begin{array}{l}\text { Phoenix Multicul- } \\
\text { tural Academy } \\
\text { 2012-2013 }\end{array}$ & $\begin{array}{l}\text { Parents in school } \\
\text { participated in pol- } \\
\text { icy advocacy work- } \\
\text { shop to address } \\
\text { 8th grade to high } \\
\text { school transition/ } \\
\text { exclusion. }\end{array}$ & $\begin{array}{l}\text { Set policy change } \\
\text { priority, framed } \\
\text { message, devel- } \\
\text { oped strategic } \\
\text { questions for } \\
\text { meeting with deci- } \\
\text { sion-maker }\end{array}$ & $\begin{array}{l}\text { Parents prepared } \\
\text { and presented } \\
\text { specific questions } \\
\text { to school system } \\
\text { Chancellor at com- } \\
\text { munity forum. }\end{array}$ & $\begin{array}{l}\text { After a follow-up } \\
\text { meeting with } \\
\text { parents, the } \\
\text { Chancellor directed } \\
\text { principal to stop } \\
\text { exclusionary prac- } \\
\text { tices. }\end{array}$ & $\begin{array}{l}\text { Increased leader- } \\
\text { ship, participation, } \\
\text { skills and resourc- } \\
\text { es of parents; } \\
\text { empowered parent } \\
\text { and community } \\
\text { involvement. }\end{array}$ \\
\hline
\end{tabular}

group/organization, the type of training they received, and the priority concern that the community wanted to address, for example, blight, safety, and high school graduation rates. The next two columns describe specific skills learned in the training and how community members used those skills to communicate with key decision-makers to influence policy change. The last two columns present the short-term specific changes as a result of their efforts, and the ways in which engaging in policy advocacy enhanced political empowerment and longer term community capacity to have a voice in the decisions affecting the community.

For example, in the first case in the table, NWP carried out an initial workshop series in 2007-2008 with the recently established Cody Rouge Community Action Alliance (CRCAA), followed by informal ongoing support for both youth and adult groups (columns 1-2). By 2012, CRCAA had prioritized reducing blight, particularly around the high school, and had organized successful cleanup/board-up programs and a resident safety patrol. Working with community leaders, NWP held another training series focused specifically on policy strategies to establish a blight-free zone around schools. CRCAA applied policy advocacy skills from the trainings to reframe their efforts, gather data, hold a media campaign, and meet with a lo- cal decision-maker (columns 2-4). The short-term outcome was allocation of state funding for demolitions near the local high school (column 5). Discussing the role and impact of NWP, the CRCAA director said, "This campaign was a direct result of the work you all [NWP] did with us to expand our focus and skills for policy change!" (Kenyetta Campbell, personal communication with Chris Coombe, September 2013, informal interview). The NWP training activities enhanced longer-term community capacity (column 6) in the following dimensions: leadership, skills, resources, and power to influence decisions affecting their community. The table presents other selected accomplishments by the focus area of the policy effort, and lists in the final column the impacts on dimensions of community capacity for each of the illustrative groups/ organizations.

\section{Case Example: Application and Integration of Policy Advocacy Capacity at the Detroit Hispanic Development Corporation}

Rooted in Detroit's vibrant Latino community, the Detroit Hispanic Development Corporation (DHDC - dhdc1.org) is a longstanding nonprofit organization committed to make a difference by creating life changing opportunities for youth and 
their families. DHDC's founder and director, Angela Reyes (a co-author on this paper), was a member of the core group that initially developed NWP and continues to be engaged in the Detroit URC's continuing policy advocacy training. She is engaged in policy advocacy at local, state, and national levels and is a leader in a statewide coalition to reform Michigan education policies. She has been a Board member of the Detroit URC since 1995.

DHDC program participants, staff, and other community residents participated in the initial NWP workshops in 2007. Since that time, the Detroit URC has conducted additional bi-lingual policy workshops with DHDC to address such communityidentified issues as gang prevention, environmental justice, vacancy and blight, immigrant rights, and school reform. DHDC has integrated policy advocacy concepts and tools into staff training, leadership development, and ongoing programs for youth and families in order to increase community residents' capacity as agents of change in their families and communities. For example, a youth who first participated in 2007 was hired several years later to direct the organization's youth programs, incorporating policy into all programming.

DHDC uses the policy advocacy training and resources not only within the organization, but in the wider community to create a culture of policy advocacy and organizing. DHDC's community organizing department transfers skills and tools learned from the policy advocacy training (e.g., powermapping, identifying the issue, framing messages) to organize campaigns for community level change on a number of issues. For example, parent groups from several schools have joined together to organize across schools to implement education reform for the city (Padres en Accion). At the high school level, youth are organizing to require that student councils be elected rather than appointed by school officials. A State legislator volunteered to work with them and they applied advocacy skills such as powermapping, framing messages, and mobilizing allies to engage in this process. Youth are also applying the policy advocacy skills to environmental justice issues, including how to do research, identify policy solutions, map power, and frame messages. In the process, youth are developing leadership skills, building social and organizational networks, strengthening community identity while also building allies, and developing their own voices and power.

Drawing from the NWP curriculum, DHDC leads and trains other grassroots groups working on policy change, such as 482Forward and members of the Southwest Detroit Colectivo Project. These efforts are designed to strengthen the Detroit Lati- no community's voice and increase their capacity to participate in democratic processes, to address the systemic barriers affecting the Detroit Latino community's equitable access to resources and opportunities for economic and political power, selfdetermination, and social justice. The Colectivo members used policy advocacy skills to pass a municipal ID ordinance and to organize residents and businesses to get parking kiosks removed because they were hurting local residents and businesses. The group used powermapping and research skills to identify who had authority to remove the kiosks. These skills are particularly important in contexts where decision-making authority is not transparent. Policy advocacy training is also integrated into support for small grant recipients, including a Latino women's group working to get bilingual city services enforced, who learned how to focus efforts on who has the power.

\section{Discussion}

There have been few studies of the impact of advocacy training programs on building community capacity for policy change, despite recognition that engaging local communities in advocacy processes is essential for policy change, and that successful policy advocacy requires a set of specific skills and capacities. This paper addresses this gap by examining the impact of the NWP policy capacity building approach on key dimensions of community capacity. Further, the paper describes how a long-standing community academic partnership (the Detroit URC) used a community-based participatory approach to design and implement NWP, that built on local knowledge and strengths to further enhance community capacity toward greater health equity.

The findings from multiple sources presented here indicate that NWP training and ongoing support activities had an impact on several key dimensions of community capacity that are essential to policy change. First we discuss and analyze the findings in relation to several specific dimensions of community capacity: leadership, participation, and community power. Then we discuss the integration of those and other dimensions of community capacity more broadly, as participants applied their strengthened capacities for policy change in their communities.

\section{Leadership and Participation}

A wide range of adults and youth attended the training workshops, some of whom were involved in organizations and others who were not. Thus, NWP 
both engaged existing community leaders and fostered leadership and participation among residents who had not been active in policy change. Given the context of both disenfranchisement and substantial community strengths described earlier, NWP built upon existing community capacity, including grassroots and organizational leadership, networks, and history of political action. Several findings indicated that NWP contributed to enhanced community participation. Training participants' positive reports of satisfaction, usefulness, and relevance are important for fostering engagement. Expressed high intentions to apply the training to work for policy change is important because behavioral intention is widely considered to be an antecedent to behavior change (Webb \& Sheeran, 2006).

\section{Community Power}

Enhancing participation, intention to work with others for change, and a sense of efficacy and community power are especially critical for communities that have experienced disenfranchisement. An important finding for future engagement and sense of power is that participants from diverse groups (e.g., youth, adults, organization leaders, unaffiliated residents) reported a statistically significant increase in self-efficacy after the initial training series, and others who participated in subsequent trainings largely reported high levels of collective efficacy. Both self-efficacy, the belief in one's ability to succeed in a specific situation, and collectiveefficacy, the shared belief in a group's ability to take action and solve problems (Bandura, 1997), play key roles in engaging people in policy change efforts to improve public health (Wallack, 1993). Empowerment was exemplified by participants speaking for the first time at town hall meetings, communicating with policy makers, and taking leadership roles in the policy advocacy efforts. In the case of youth, the policy advocacy workshops and ongoing support over several years enabled young people to gradually develop skills and confidence that they put into action through youth development programs of which they were a part. In general, youth are seldom asked to engage in community problem solving and action (Awan et al., 2016), particularly by adults, and the training experience provided tools for subsequent organizing (highlighted in Table 2).

\section{Integration of Multiple Dimensions of Community Capacity - NWP Applied for Policy Change}

Evaluation results from the trainings as well as the examples of how NWP was applied by orga- nizations toward policy change demonstrate the integration of multiple dimensions of capacity. Participants reported aspects of both the content and process that were important to them, including knowledge, skills, and tools essential for carrying out successful advocacy campaigns. The findings indicate that several organizations that received both training and support applied what they learned to issues of importance to them, using capacities for critical reflection, problem-solving, and analysis. The experiential approach to the training and support activities was based on adult education theories that adults are more likely to learn and apply new skills when they have had an opportunity to practice them using issues of relevance and importance to them (Johnson \& Johnson, 2017). In some cases, for example CRCAA, the support provided by NWP enabled them to expand their community action from short-term programs (e.g., neighborhood clean-ups, board ups) to more policy-oriented solutions (e.g., "zoning" areas as blight-free, reordering funding priorities, and targeted enforcement against large-scale violators of the anti-blight ordinance).

\section{Community-based Participatory Approach}

The Detroit URC, a longstanding communitybased participatory research partnership, drew on nearly two decades of experience as well as guidance from PolicyLink in establishing NWP. NWP was designed and implemented using a communitybased participatory approach by longtime, experienced community and academic partners. The policy- and issue-specific knowledge and expertise and lived experience of the Detroit-based partners was key to the success of both the content and process of the training. Further, the active engagement of community and academic partners in the process of developing and conducting the training was critical to and strengthened our capacity to work together while simultaneously building capacity as a process and outcome among those who were trained.

Using an equitable community-based participatory approach throughout, NWP built new and strengthened existing relationships between community leaders and residents, the policy trainers, foundations, and public officials. As leaders themselves, the community policy trainers are wellrespected and connected in the community, have a critical understanding of history and power in Detroit, and are highly engaged in policy-related initiatives, networks, and issues. Thus, the trainers played an essential role in transferring knowledge, skills, and connections to participants. Further, they were able to integrate policy capacity building into 
their organizations and work, thus further enhancing community capacity dimensions of skills, resources, networks, and power. For example, a policy trainer hired two youth involved in NWP policy work as summer interns at her organization through a grant she received, and another policy trainer was elected to serve on the board of a key citywide education organization. This capacity building was particularly timely, as there were increasing opportunities for widespread engagement in emerging initiatives focused on regeneration and change in Detroit.

\section{Building Capacity for Policy Change in Disenfranchised Communities}

An important result of NWP was increased understanding of the difference between programs and policies, and the knowledge that "policy" encompasses more than legislation, as indicated in the findings presented in this article. Given past and current political disenfranchisement in Detroit (e.g., emergency managers governing both the city and schools, state legislature and governor under single-party control), it was important that NWP go beyond more traditional training programs that focus on how to pass legislation. For example, although community activists passed both a city ordinance and a ballot proposition requiring developers to negotiate community benefits agreements, the state legislature countered by passing a law to preempt local authority. Thus, the NWP training activities focused primarily on "little p" policies such as enforcement, budgets, organizational policies, and administrative rules that would bypass the higher level decision-making structure over which residents had little influence or control. Building the capacity to develop such strategies is more important than ever in the current political environment.

\section{Limitations}

There are several limitations to this study. First, although NWP developed a core training curriculum consisting of separate modules, the training was carried out in multiple formats for widely different groups, limiting comparability of evaluation findings across participants. Further, it was not feasible within the context of this program and budget to track and follow participants over time. This precluded our ability to document specific impacts on policies and health equity that may have emerged from this effort. However, because of the community-based approach and longstanding relationships, we were able to follow and document policy advocacy activities of some of the organi- zations that continued to request NWP support, as presented in this article. Future efforts need to evaluate more clearly how such policy advocacy training impacts decisions over time.

Second, the fluid policy environment in Detroit created particular challenges for training and engaging communities in policy processes. For example, it was difficult for both trainers and participants to identify who is in power, where to intervene, and how to build relationships with decision-makers who are not accountable to the population. Hence, some of the key knowledge and processes for changing policies may be less effective under these conditions. In addition, specific policy training materials and resources needed frequent updating.

Finally, both community capacity and policy change are long-term endeavors that can be difficult to track and evaluate (Guthrie, Louie, David, \& Foster, 2005; Liberato, Brimblecombe, Ritchie, Ferguson, \& Coveney, 2011). While a long-term aim of NWP was to impact policies toward creating healthy neighborhoods, we are unable to ascribe causality to the program and outcomes reported here.

Despite these limitations, there are a number of strengths to the efforts described here. These include active engagement of community and academic partners using participatory processes, clear description of the dimensions of capacity addressed in the training and that can be adapted by others, and evidence of effective advocacy to impact determinants of health at the local level.

\section{Implications for Scholarship and Practice}

We have identified several implications for future engaged scholarship and practice to build capacity for policy change in order to address social determinants of health and health equity. First, using a community-based participatory approach to engage both academics and community leaders in the development and implementation of the training builds on existing leadership and strengths of the community, and enhances transfer of capacities across many levels. Second, using a community capacity building framework ensures attention to multiple dimensions in training programs that are necessary for successfully enhancing the knowledge and skills needed to subsequently achieve policy change. The NWP strategy to build capacity for policy change rather than directly initiate and carry out a specific policy campaign is consistent with the Detroit URC's overall approach to communityacademic engagement. Supporting the ability of communities to engage in policy change processes helps to ensure power and determination of Detroit 
residents and communities. Communities can apply enhanced capacity in leadership, participation, skills, and power, for example, to multiple issues, outcomes, and policy opportunities that arise. Third, embedding the policy advocacy work in existing organizations, as in the case of DHDC, further ensures that the enhanced capacity that results from the training is institutionalized and sustained. Finally, how to achieve policy change in the context of longstanding and escalating disenfranchisement is a critical question that needs further scholarly and practice attention. Equitable community-academic partnerships can provide an excellent process and setting to address this question.

\section{Conclusion}

In this study, we examined community capacities strengthened through the development and implementation of the NWP initiative, using a community-based participatory approach to build capacity for policy change toward the long-term goal of enhancing community well-being and equity. Both community capacity building and policy change are long-term endeavors that can benefit from academic and community collaboration, and that require sustained effort over time. Thus, strategies that build upon existing partnerships and community leadership and strengths, while enhancing participation of all residents can contribute to longer term sustainability of communities' ability to promote healthy policy and equity.

While this initiative was situated in Detroit, the approach is relevant to other urban communities undergoing massive changes which will impact the present and future for residents, neighborhoods, and cities, as well as for the country as a whole. Helping people regain their sense of power and agency builds and sustains community capacity to have and use their voices to influence decisions about the distribution of resources such as housing, education, employment opportunities, and other social determinants of health. Efforts such as this help to strengthen local capacity to engage in policy analysis and action to influence decision making in a manner that can contribute to more equitable distribution of the social determinants of health, and ultimately to more equitable health outcomes.

\section{Note}

The authors appreciate the contributions to the work described in this article of all partners involved in the Detroit Urban Research Center (Community Health and Social Services Center, Communities In Schools, Detroit Health Department, Detroit His- panic Development Corporation, Detroiters Working for Environmental Justice, Friends of Parkside, Henry Ford Health System, Institute for Population Health, Latino Family Services, Neighborhood Service Organization, Eastside Community Network, and University of Michigan Schools of Public Health, Nursing, and Social Work); the trainers and staff involved in the Neighborhoods Working in Partnership project and subsequent policy capacitybuilding efforts; and our colleagues at PolicyLink. The work presented here was supported in part by The Skillman Foundation, the University of Michigan, and the Robert Wood Johnson Foundation.

\section{References}

Awan, A. N., M. Brennan, P. Dolan, E. Graeff, S. Huxley, A.F. Huziak et al. (2016). United Nations World Youth Report 2016, The Department of Economic and Social Affairs. New York: United Nations.

Bandura, A. (1997). Self-efficacy: The exercise of control. New York: W.H. Freeman.

Boggs, G. L., \& Kurashige, S. (2012). The next American revolution: Sustainable activism for the twenty-first century. Oakland, CA: University of California Press.

Braveman, P. A., Cubbin, C., Egerter, S., Williams, D. R., \& Pamuk, E. (2010). Socioeconomic disparities in health in the United States: What the patterns tell us. American Journal of Public Health, 100 Suppl 1, S186-196. doi: 10.2105/ajph.2009.166082

Browner, E. S., \& Preziosi, R. C. (1995). Using experiential learning to improve quality. In D. Van Tiem, J.L. Mosely, J.C. (Eds.) Fundamentals of performance improvement: Optimizing results through people, process, and organizations (pp. 168-174). San Francisco: Pfeiffer.

Cheezum, R. R., Coombe, C. M., Israel, B. A., McGranaghan, R. J., Burris, A. N. et al. (2013). Building community capacity to advocate for policy change: An outcome evaluation of the Neighborhoods Working in Partnership Project in Detroit. Journal of Community Practice, 21(3), 228-247. doi: 10.1080/10705422.2013.811624

Clynes, M. (2013). Neighborhoods working in partnership: Youth mobilizing for policy change. Michigan NightLight Illuminating Solutions for Children. Retrieved from http://www.michigannightlight.com/pro grams/youthmobilizingforpolicychange.aspx

Colombo, M. (2016). 10 years of place-based work, Kids Matter Here: An analytic review of the 10-year Good Neighborhoods Initiative. Retrieved from http://www. skillman.org/Knowledge-Center/Data-Evaluation-Re ports/10-years-of-place-based-work

Coombe, C. M. (2012). Participatory approaches to evaluating community organizing and coalition building. In M. Minkler (Ed.), Community building and community organizing for health and welfare (3rd ed., pp. 346-403). New Brunswick, NJ: Rutgers University Press. 
Detroit Works Project. (2012). Detroit future city: 2012 Detroit strategic framework plan. Detroit, MI: Inland Press. Retrieved from https://detroitfuturecity.com/ wp-content/uploads/2014/12/DFC_Full_2nd.pdf

Dewar, M. E., \& Thomas, J. M. (2013). The city after abandonment. Philadelphia: University of Pennsylvania Press.

Farley, R., Danziger, S., \& Holzer, H. J. (2000). Detroit divided. New York: Russell Sage Foundation.

Freudenberg, N. (2004). Community capacity for environmental health promotion: Determinants and implications for practice. Health education \& behavior : the official publication of the Society for Public Health Education, 31(4), 472-490. doi: $10.1177 / 1090198104265599$

Freudenberg, N., Pastor, M., \& Israel, B. (2011). Strengthening community capacity to participate in making decisions to reduce disproportionate environmental exposures. American Journal of Public Health, 101(Suppl 1), S123-S130. doi: 10.2105/ AJPH.2011.300265

Freudenberg, N., Rogers, M., Ritas, C., \& Nerney, S. M. (2005). Policy analysis and advocacy. In B. Israel, E. Eng, A. Schulz, \& E. Parker (Eds.), Methods in community-based participatory research for health (pp. 349-370). San Franciso: Jossey-Bass.

Freudenberg, N., \& Tsui, E. (2014). Evidence, power, and policy change in community-based participatory research. American Journal of Public Health, 104(1), 11-14. doi: 10.2105/ajph.2013.301471

Goodman, R. M., Speers, M. A., McLeroy, K., Fawcett, S., Kegler, M., Parker, E. et al. (1998). Identifying and defining the dimensions of community capacity to provide a basis for measurement. Health Education \& Behavior, 25(3), 258-278.

Guthrie, K., Louie, J., David, T., \& Foster, C. C. (2005). The challenge of assessing policy and advocacy activities. Los Angeles: The California Endowment.

Israel, B. A., Coombe, C. M., Cheezum, R. R., Schulz, A. J., McGranaghan, R., Lichtenstein, R. et al. (2010). Community-based participatory research: A capacity building approach for policy advocacy aimed at eliminating health disparities. American Journal of Public Health, 100, 2094-2102. doi: 10.2105/ ajph.2009.170506

Israel, B. A., Lichtenstein, R., Lantz, P., McGranaghan, R., Allen, A., Guzman, J. R. et al. (2001). The Detroit Community-Academic Urban Research Center: Development, implementation, and evaluation. Journal of Public Health Management and Practice, 7(5), 1-19.

Israel, B. A., Schulz, A. J., Parker, E. A., \& Becker, A. B. (2001). Community-based participatory research: Policy recommendations for promoting a partnership approach in health research. Education for Health, 14(2), 182-197. doi: 10.1080/13576280110051055

Johnson, D. W., \& Johnson, F. P. (2017). Joining together: Group theory and group skills (12th ed.). Essex, UK: Pearson Education Limited.

Kinney, R. J. (2016). Beautiful wasteland: The rise of Detroit as America's postindustrial frontier. Minneapolis, MN: University of Minnesota Press.
Kolb, D. A. (1984). Experiential learning: Experience as the source of learning and development. Englewood Cliffs: Prentice-Hall.

Legislature, Michigan. (2011). Act 4 of 2011 Local Government and School District Fiscal Accountability Act. Lansing: Michigan Compiled Laws. Retrieved from http://www.legislature.mi.gov/(S(xnh4yjlbaajpehybi zm2yhe 1) $/$ mileg .aspx ?page $=$ GetObject\&objectnam $\mathrm{e}=$ mcl-act-4-of-2011

Legislature, Michigan. (2012). Local Financial Stability and Choice Act. Lansing: Michigan Compiled Laws. Retrieved from http://www.legislature.mi.gov/(S(0fjo e0fij3hubuydcefqqntg))/mileg.aspx ?page $=\mathrm{GetOb}$ ject\&objectname $=$ mcl-act-436-of-2012

Liberato, S. C., Brimblecombe, J., Ritchie, J., Ferguson, M., \& Coveney, J. (2011). Measuring capacity building in communities: A review of the literature. BioMed Central Public Health, 11(1), 1-10. doi: 10.1186/1471-2458-11-850

Link, B. G., \& Phelan, J. (1995). Social conditions as fundamental causes of disease. Journal of Health and Social Behavior, 36 (Special issue), 80-94.

Minkler, M., Vásquez, V. B., Chang, C., \& Miller, J. (2009). Promoting healthy public policy through community-based participatory research: Ten case studies. Oakland, CA: University of California Berkeley School of Public Health Team.

Minkler, M., Vasquez, V. B., Tajik, M., \& Petersen, D. (2008). Promoting environmental justice through community-based participatory research: The role of community and partnership capacity. Health Education \& Behavior, 35(1), 119-137. doi: 10.1177/1090198106287692

Minkler, M., \& Wallerstein, N. (2008). Communitybased participatory research for health: From process to outcomes. San Francisco: Jossey-Bass.

Patton, M. Q. (2002). Qualitative evaluation and research methods (3rd ed.). Newbury Park, CA: Sage.

Phelan, J. C., Link, B. G., \& Tehranifar, P. (2010). Social conditions as fundamental causes of health inequalities: theory, evidence, and policy implications. Journal of Health and Social Behavior, 51 Supplement, S28-40. doi: 51/1_suppl/S28 [pii] 10.1177/0022146510383498

Ritas, C. (2003). Speaking truth, creating power: A guide to policy work for community-based participatory research practitioners. Seattle, WA: Community Campus Partnerships for Health.

Roe, K. M., Minkler, M., \& Saunders, F. F. (1995). Combining research, advocacy, and education: The methods of the Grandparent Caregiver Study. Health Education Quarterly, 22(4), 458-475.

Schulz, A., \& Northridge, M. E. (2004). Social determinants of health: Implications for environmental health promotion. Health Education \& Behavior, 31(4), 455471. doi: $10.1177 / 1090198104265598$

Schulz, A. J., Williams, D. R., Israel, B. A., \& Lempert, L. B. (2002). Racial and spatial relations as fundamental determinants of health in Detroit. The Milbank Quarterly, 80(4), 677-707. doi: 10.1111/1468-0009.00028 
Sharpe, P. A., Flint, S., Burroughs-Girardi, E. L., Pekuri, L., Wilcox, S., \& Forthofer, M. (2015). Building capacity in disadvantaged communities: Development of the community advocacy and leadership program. Progress in Community Health Partnerships, 9(1), 113-127. doi: 10.1353/cpr.2015.0003

Smith, M. P., \& Kirkpatrick, L. O. (2015). Reinventing Detroit: The politics of possibility, New Brunswick, NJ: Transaction Publishers.

Sugrue, T. J. (1996). The origins of the urban crisis: Race and inequality in postwar Detroit. Princeton, NJ: Princeton University Press.

Themba, M. (1999). Making policy, making change: How communities are taking law into their own hands ( $1^{\text {st }}$ ed.). San Francisco: Jossey-Bass.

Themba, M., \& Minkler, M. (2003). Influencing policy through community based participatory research. In M. Minkler \& N. Wallerstein (Eds.), Community based participatory research for health (pp. 349-370). San Francisco: Jossey-Bass.

Themba-Nixon, M., Minkler, M., \& Freudenberg, N. (2008). The role of CBPR in policy advocacy. In M. Minkler \& N. Wallerstein (Eds.), Community-based participatory research for health: From process to outcomes (2nd ed., pp. 307-322). San Francisco: JosseyBass.

Thomas, J. M., \& Bekkering, H. (2015). Mapping Detroit: Land, community, and shaping a city. Detroit, MI: Wayne State University Press.

Thompson, H. A. (2001). Whose Detroit?: Politics, labor, and race in a modern American city. Ithaca, NY: Cornell University Press.

Tsui, E., Cho, M., \& Freudenberg, N. (2013). Methods for community-based participatory policy work to improve food environments in New York City. In B. Israel, E. Eng, A. Schulz, E. Parker (Eds.), Methods for community-based participatory research for health (pp. 517-545). San Francisco: Jossey-Bass.

Wallack, L. M. (1993). Media advocacy and public health: power for prevention. Newbury Park, CA: Sage Publications.

Ward, S. M. (2016). In love and struggle: The revolutionary lives of James and Grace Lee Boggs. Chapel Hill, NC: UNC Press Books.

Webb, T. L., \& Sheeran, P. (2006). Does changing behavioral intentions engender behavior change? A meta-analysis of the experimental evidence. Psychological Bulletin, 132(2), 249-268. doi: 10.1037/00332909.132.2.249

Williams, D. R., \& Collins, C. (2001). Racial residential segregation: A fundamental cause of racial disparities in health. Public Health Reports, 116, 404-416.

Williams, D. R., \& Jackson, P. B. (2005). Social sources of racial disparities in health. Health Affairs (Millwood), 24(2), 325-334. doi: 10.1377/hlthaff.24.2.325
Authors

CHRIS M. COOMBE (ccoombe@umich.edu) is assistant research scientist at the University of Michigan School of Public Health, with extensive experience designing, implementing, and evaluating collaborative research and interventions using a community-based participatory research (CBPR) approach. Her work focuses on understanding how urban social and physical environments contribute to racial and socioeconomic inequities, and translating that knowledge into policy interventions to promote health and equity.

BARBARA A. ISRAEL (ilanais@umich.edu) is a professor in the Department of Health Behavior and Health Education at the University of Michigan School of Public Health. She has extensive experience conducting CBPR in collaboration with partners in diverse communities. Since 1995, she has worked together with academic and community partners to establish and maintain the Detroit Urban Research Center. She is actively involved in several Detroit URC-affiliated partnerships examining and addressing, for example, the environmental triggers of childhood asthma, the social and physical environmental determinants of cardiovascular disease, and capacity building for and translating research findings into policy change.

ANGELA G. REYES (agreyes@dhdc1.org) is the founder and executive director of the Detroit Hispanic Development Corporation and a founding board member of the Detroit CommunityAcademic Urban Research Center. She has been active in community organizing efforts in Southwest Detroit for more than 30 years. Ms. Reyes is the recipient of several awards, including Corp! Magazine's Michigan's Most Influential Hispanic Leaders, New Detroit's Closing the Gap Award, and the Detroit Metropolitan Bar Association Liberty Bell Award. Ms. Reyes is known nationally and internationally as a consultant and speaker on issues affecting the Latino community, including cultural awareness, youth gangs and violence, immigration, and education reform.

JAYE CLEMENT (jclemen1@hfhs.org) is the director of Community Health Programs and Strategies with the Office of Community Health, Equity and Wellness at Henry Ford Health System in Detroit, Michigan. She is a Fellow with the W.K. Kellogg Foundation's Community Leadership Network. She also works closely with the Detroit Community-Academic Urban Research Center (URC) as a Community Policy Advocacy Trainer for the Neighborhoods Working in Partnership: Building Capacity for Policy Change Project, serves on the board of directors for the local non- 
profit, Teen HYPE (Helping Youth by Providing Education) and on the advisory board for Black Mother's Breastfeeding Association.

SONYA GRANT (sonya.grant@semca.org) is the chief operating officer with the Southeast Michigan Community Alliance (SEMCA), a statedesignated Michigan Works! designee. Formerly, she was the project manager for Community Action Against Asthma (CAAA), a CBPR partnership affiliated with the Detroit URC. She has worked in a variety of social service and community development positions in Detroit, including executive director for City Camp, a youth summer program, executive director for Rebuilding Communities Inc. (RCI), and as a legislative aide to the Detroit City Council President. Ms. Grant has been a community Policy Advocacy trainer with the Detroit URC's Neighborhoods Working in Partnership program since its inception in 2007.

RICHARD LICHTENSTEIN (lichto@umich. edu) is the S. J. Axelrod Collegiate Professor of Health Management and Policy at the University of Michigan School of Public Health. In addition to being a founding board member of the Detroit $\mathrm{URC}$, he is the retired director of the University of Michigan Summer Enrichment Program in Health Management, an internship program for undergraduate students interested in eliminating health disparities. He serves on the board of directors of the Neighborhood Service Organization in Detroit and the Corner Health Center in Ypsilanti, Michigan. He is also a trustee of two Voluntary Employee Beneficiary Associations (VEBAs), which provide health benefits to groups of retirees.
AMY J. SCHULZ (ajschulz@umich.edu) is a professor of Health Behavior and Health Education at the University of Michigan School of Public Health. She has published extensively on community-based participatory research and social and environmental determinants of health in urban communities, as well as cumulative risk. She is the principal investigator of the Healthy Environments Partnership, an affiliated partnership of the Detroit URC focused on examining and addressing social and environmental factors associated with cardiovascular inequities in Detroit, and multi-PI for Community Action to Promote Healthy Environments, a community based participatory research effort to develop and implement a public health action plan to improve air quality and reduce adverse effects on health.

SHERITA SMITH (ssmith@dhdc1.org) is director of development at Detroit Hispanic Development Corporation. She has extensive experience engaging in community organizing and policy advocacy efforts, particularly around health issues, and is very familiar with community-based participatory research processes. She has been involved in several long-term CBPR, community planning and evaluation efforts, and is a highly engaged partner of the Detroit URC and affiliated partnerships. She served as a policy trainer for the Neighborhoods Working in Partnership project, and a policy specialist for the Neighborhoods Taking Action partnership. 